\title{
DNA ALKYLATION AND FORMATION OF DNA INTERSTRAND CROSS-LINKS BY POTENTIAL ANTITUMOUR 2,5-BIS(1-AZIRIDINYL)-1,4-BENZOQUINONES
}

KLAAS J. LUSTHOF", NICOLAAS J. DE MOL*, LAMBERT H.M. JANSSEN^, WILLEM VERBOOM $^{\mathrm{b}}$ and DAVID N. REINHOUDT ${ }^{\mathrm{b}}$

-Department of Pharmaceutical Chemistry, Faculty of Pharmacy, University of Utrecht, Catharijesingel 60, 3511 GH Utrecht and ${ }^{\circ}$ Department of Organic Chemistry, University of Twente, P.O. Box 217, 7500 AE Enschede (The Netherlands)

(Received July 22nd, 1988)

(Revision received November 9th, 1988)

(Accepted November 22nd, 1988)

\section{SUMMARY}

A series of 3,6-substituted 2,5-bis(1-aziridinyl)-1,4-benzoquinone derivatives was shown to alkylate calf thymus DNA and to form DNA interstrand crosslinks. Alkylation and cross-link formation were enhanced after electrochemical reduction of the compounds and increased with lower $\mathrm{pH}$ in the $\mathrm{pH}$ range from 4.5 to 8.0. Reduction especially shifts the $\mathrm{pH}$ at which cross-linking and alkylation occurs to higher values, which are more physiologically relevant. This shift is probably caused by the increase in $\mathrm{p} K_{a}$ value of the aziridine ring after reduction of the quinone moiety. The inactivation of singlestranded bacteriophage M13mp19 DNA to form phages in an $E$. coli host, by the 3,6-unsubstituted parent compound 2,5-bis(1-aziridinyl)-1,4-benzoquinone (TW13) was dependent upon reduction and $\mathrm{pH}$ in a similar way as was alkylation. The compound in our series with the least bulky, 3,6-substitutents, TW13, caused a high amount of cross-link formation. Compounds with methyl-substituted aziridine rings showed low cross-linking ability. Our results support the concept that the protonated reduced compound is the reactive species that alkylates DNA, and that steric factors play an important role in the reactivity towards DNA. A correlation is observed between the ability to induce DNA interstrand cross-links and inactivation of M13mp19 bacteriophage DNA. Cross-link formation was also demonstrated in $E$. coli $\mathrm{K} 12$ cells, where the compounds are reduced endogenously by bacterial reductases.

Abbreviations: AZQ, 2,5-bis(1-aziridinyl)-3,5-bis(carboethoxyamino)-1,4-benzoquinone; BABQ, 2,5bis(1-aziridinyl)-1,4-benzoquinone; CbQ, Carboquone (2,5-bis(1-aziridinyl)-3-2-(carbamoyloxy)-1methoxyethyl-6-methyl-1,4-benzoquinone) DMF, N,N-dimethylformamide. 
Key words: DNA alkylation - Antitumour drugs - DNA interstrand crosslinks - Reductive activation

INTRODUCTION

Among the frequently used antitumour drugs in clinical use today, are many drugs containing a quinone moiety like mitomycin $\mathrm{C}$, adriamycin and daunorubicin. It is generally assumed that these compounds are bioreductively activated to alkylating species. They are therefore potentially useful drugs especially against solid tumours, because the cells of these tumours have a low oxygen tension as a consequence of poor vascularity [1].

Based on AZQ and related compounds evaluated by Driscoll et al. [2] we synthesized a series of 3,6-substituted 2,5-bis(1-aziridinyl)-1,4-benzoquinone (BABQ) derivatives (Fig. 1 and Table I). The quinone moiety can be reduced in two one electron steps via the semiquinone radical to the hydroquinone. After reduction, protonation of the aziridine ring is facilitated and an electrophilic species is formed. The slightly acidic $\mathrm{pH}$ of tumour cells additionally might activate this protonation [3]. The electrophilic species is capable of covalent binding to DNA as is shown for AZQ [4] and aziridine radiosensitizers [5].

The $\mathrm{BABQ}$ derivatives contain two aziridinyl groups enabling them to react bifunctionally to form DNA cross-links, as demonstrated for AZQ $[4,6]$. Generally DNA cross-links are more lethal than monoadducts [7].

In a previous paper [8] we reported the effects of these compounds on DNA, as studied with inactivation of M13mp19 single strand bacteriophage DNA and inhibition of colony forming ability of a DNA repair deficient $E$. coli K12 strain. In the present paper we report on a study of the alkylating properties of the $\mathrm{BABQ}$ derivatives. In particular the effect of $\mathrm{pH}$ and reductive activation on DNA alkylation and cross-linking by BABQ derivatives<smiles>[R2]C1=C(N2CC2[R3])C(=O)C([R7])=C(N2CC2[R3])C1=O</smiles>

Fig. 1. General structure of 2,5-bis(1-aziridinyl)-1,4-benzoquinones. 
TABLE I

STRUCTURES OF 2,5-bis(1-AZIRIDINYL)1,4-BENZOQUINONES

\begin{tabular}{llll}
\hline Compound & $\mathrm{R}_{1}$ & $\mathrm{R}_{2}$ & $\mathrm{R}_{3}$ \\
\hline AZq & NHCOOEt & NHCOOEt & $\mathrm{H}$ \\
TW 73 & NHCOOEt & NHCOOEt & $\mathrm{CH}_{3}$ \\
TW 53 & $\mathrm{CH}_{3}$ & $\mathrm{Br}$ & $\mathrm{CH}_{3}$ \\
TW 87 & $\mathrm{CH}_{3}$ & $\left(\mathrm{CH}_{2}\right)_{2} \mathrm{OCONH}_{2}$ & $\mathrm{CH}_{3}$ \\
CbQ & $\mathrm{CH}_{3}$ & $\mathrm{CH}_{2}\left(\mathrm{OCH}_{8}\right) \mathrm{CH}_{2} \mathrm{OCONH}_{2}$ & $\mathrm{H}$ \\
TW 32 & $\mathrm{CH}_{3}$ & $\mathrm{C}_{2} \mathrm{H}_{3}$ & $\mathrm{H}$ \\
TW 25 & $\mathrm{Br}$ & $\mathrm{C}_{2} \mathrm{H}_{5}$ & $\mathrm{H}$ \\
TW 39 & $\mathrm{CH}$ & $\left(\mathrm{CH}_{2}\right)_{2} \mathrm{OCONH}_{2}$ & $\mathrm{H}$ \\
TW 13 & $\mathrm{H}$ & $\mathrm{H}$ & $\mathrm{H}$ \\
TW 26 & Aziridinyl & $\mathrm{F}$ & $\mathrm{H}$ \\
\end{tabular}

was investigated. Cross-link formation was determined with the ethidium bromide fluorescence assay $[9,10]$. We also investigated the cross-link formation in intact $E$. coli cells, which activate BABQ derivatives by endogeneous bacterial reductases [8].

\section{MATERIALS AND METHODS}

The BABQ derivatives were prepared or obtained as described previously [8]. TW23 (2-(1-aziridinyl)-1,4-naphthoquinone) was prepared according to Ref. 11. Stock solutions of the BABQ derivative contained $5 \mathrm{mM}$ BABQ in DMF. Calf thymus DNA was from Sigma Chemical Company.

RNAse A (EC 3.1.27.5) was from Boehringer Mannheim. Ingredients for bacterial media were obtained grom Difco Laboratories, Detroit, Michigan. All other chemicals were of analytical grade. Water was purified by Milli-Q filtration. $E$. coli K12-343/765 and 343/753 were obtained from Prof. Mohn, R.I.V.M., Bilthoven, The Netherlands. Glucose-phosphate buffer contained 2.8 g glucose per $100 \mathrm{ml}$ in $60 \mathrm{mM}$ phosphate buffer (pH 7.1). The ethidium bromide measuring solution contained $0.5 \mu \mathrm{g} \cdot \mathrm{ml}^{-1}$ ethidium bromide and 0.4 mM EDTA in $20 \mathrm{mM}$ phosphate buffer (pH 12.0).

Electrochemical reduction was performed after saturating the solution with nitrogen in a vessel kept at $25^{\circ} \mathrm{C}$, using a radiometer $\mathrm{K} 401$ saturated calomel reference electrode, a platinum wire auxiliary electrode, a 2-ml mercury pool cathode and a Brooker E100 potentiostat. UV/VIS spectra were recorded on a Perkin-Elmer Lambda-5 spectrophotometer. Fluorescence measurements were performed on a Perkin-Elmer LS-3 fluorescence spectrometer.

Alkylation of calf thymus DNA by TW13

A solution containing $0.5 \mathrm{mM}$ TW13 in $50 \mathrm{mM}$ TRIS-acetate buffer (pH 7.0) containing 10\% DMF from the TW13 stock solution, was electro- 
chemically reduced in the dark at a potential that was $200 \mathrm{mV}$ more negative than the half wave potential value of TW13 (-105 $\mathrm{mV}$ at $\mathrm{pH} 7$ against $\mathrm{Ag} /$ $\mathrm{AgCl}$ [14]), until at least $90 \%$ of the compound was reduced as estimated from the limiting current. Usually this was achieved within $20 \mathrm{~min}$. The initial cathode current was $75 \mu \mathrm{A}$. From this solution $200 \mu \mathrm{l}$ was directly added to $200 \mu \mathrm{l}$ of a solution containing $1.2 \mathrm{mg} \cdot \mathrm{ml}^{-1}$ calf thymus DNA in $200 \mathrm{mM}$ TRIS-acetate buffer with a $\mathrm{pH}$ varying from 4.5 to 8.0. After incubation at $37^{\circ} \mathrm{C}$ for $60 \mathrm{~min}$, unbound TW13 was removed by spun-column chromatography over Sephadex G50 [12] and subsequent extractions with chloroform and diethylether. Sephadex G50 spun filtration removed 97\% of TW13. Extractions quantitatively removed the rest of TW13. The samples were diluted ten times and a UV/VIS spectrum was recorded. The amount of TW13 bound to DNA was expressed as the ratio between the UV maxima at $342 \mathrm{~nm}$ (maximum absorption TW13 adduct) and $260 \mathrm{~nm}$ (maximum absorption DNA).

To study the influence of the amount of reduction on alkylation, $100 \mu \mathrm{l}$ samples of the electrochemically reduced solution were taken at different time intervals and incubated with $100 \mu \mathrm{l}$ of a solution containing $1.5 \mathrm{mg} \cdot \mathrm{ml}^{-1}$ calf thymus DNA at $37^{\circ} \mathrm{C}$ for $60 \mathrm{~min}$.

The samples were then treated as described for the other samples. The amount of reduced TW13 at the time of sampling was estimated from the limiting current on the cathode.

Inactivation of single stranded bacteriophage M13mp19 DNA

M13mp19 DNA was incubated during $60 \mathrm{~min}$ at $37^{\circ} \mathrm{C}$ with $100 \mathrm{mM}$ TRIS - acetate buffer of varying $\mathrm{pH}$, in the presence of $1 \%$ TW13 stock solution (5 $\mathrm{mM}$ in DMF) or $1 \% \mathrm{DMF}$ in control experiments. The pH values of thé incubation mixtures ranged from 4.1 to 7.0 . M13mp19 DNA was also reacted with electrochemically reduced TW13. A mixture containing $0.5 \mathrm{mM}$ TW13, $10 \% \mathrm{DMF}$ and $50 \mathrm{mM}$ potassium sulfate as electrolyte, was reduced electrochemically as described above. After reduction, the mixture was diluted tenfold in $110 \mathrm{mM}$ TRIS - acetate buffers in the $\mathrm{pH}$ range 4.5 to 8.0 , containing M13mp19 DNA, and incubated at $37^{\circ} \mathrm{C}$ for $60 \mathrm{~min}$. Unbound TW13 was removed by spun-column chromatography and ethanol precipitations of DNA. The viability of M13mp19 DNA was determined as described previously [8].

\section{DNA interstrand cross-linking}

A solution, containing $0.05 \mathrm{mM} B A B Q$ derivative and $50 \mathrm{mM}$ potassium sulphate in $10 \mathrm{mM}$ TRIS - acetate buffer ( $\mathrm{pH} \mathrm{7.0)}$ (containing 1\% DMF) was electrochemically reduced as described for TW13. From this solution, $40 \mu \mathrm{l}$ was added to $360 \mu \mathrm{l}$ of a solution containing $0.67 \mathrm{mg} \cdot \mathrm{ml}^{-1}$ calf thymus DNA in $30 \mathrm{mM}$ TRIS - acetate buffer in the $\mathrm{pH}$ range from 4.5 to 8.0. The mixture was incubated for $60 \mathrm{~min}$ at $37^{\circ} \mathrm{C}$. Unbound quinone was removed by spuncolumn chromatography over Sephadex G50 and subsequent ethanol precipitations of DNA. The precipitated DNA was rehydrated in $100 \mu \mathrm{l}$ water overnight at $4^{\circ} \mathrm{C}$. In a cuvette $30 \mu \mathrm{l}$ of this DNA solution was mixed with 2 $\mathrm{ml}$ ethidium bromide measuring solution and the fluorescence was measured. 
For denaturation, the samples were put at $95^{\circ} \mathrm{C}$ during $3 \mathrm{~min}$, allowed to cool at $20^{\circ} \mathrm{C}$ during $7 \mathrm{~min}$ and measured immediately. The ratio between the fluorescence after and before denaturation $((F a / F b)$ ), compared to this ratio with a blank sample $\left((\mathrm{Fa} / \mathrm{Fb})_{b}\right)$, yielded a percentage cross-links with use of the formula [10]

$$
\% \text { cross-links }=\frac{(F a / F b)_{s}-(F a / F b)_{b}}{1-(F a / F b)_{b}} \times 100 \%
$$

N.B. It should be noted that the percentage cross-linking has no straightforward relation to the amount of base pairs that is cross-linked. The percentage cross-links in the formula is in fact the percentage return of double stranded DNA that causes fluorescence of ethidium bromide at $\mathrm{pH} 12.0$.

Cross-link formation in DNA isolated from intact $E$. coli cells

$E$. coli K12-343/765 (wild type) was grown overnight in $10 \mathrm{ml}$ nutrient broth [13], centrifuged, washed and resuspended in $7 . \mathrm{ml}$ glucose-phosphate buffer. The suspension contained approximately $10^{9}$ cells $/ \mathrm{ml}$. After addition of $50 \mu \mathrm{l}$ stock solution of TW13, the suspension was incubated at $37^{\circ} \mathrm{C}$ under shaking. The viability of the cells was previously shown to remain constant under these circumstances [8].

Samples of $400 \mu \mathrm{l}$ were diluted with $10 \mathrm{ml}$ ice-cold TRIS-EDTA solution (0.02 M TRIS (pH 7.1) and 0.02 M EDTA) and centrifuged. Bacterial DNA was isolated following the procedure of Marmur [14]. RNA was removed by incubating the samples with $40 \mu \mathrm{g} \cdot \mathrm{ml}^{-1}$. RNAse A in TRIS-EDTA buffer pH 8.0 (10 $\mathrm{mM}$ TRIS and $1 \mathrm{mM}$ EDTA), for $60 \mathrm{~min}$ at $25^{\circ} \mathrm{C}$.

\section{RESULTS AND DISCUSSION}

Alkylation of DNA by electrochemically reduced TW13 results in the formation of adducts that absorb at 342 and $260 \mathrm{~nm}$ (Fig. 2). The absorption maximum at $260 \mathrm{~nm}$ corresponds with the maximum absorption of DNA. The maximum at $342 \mathrm{~nm}$ does not correspond with that of TW13, which has maximum absorption at $324 \mathrm{~nm}$. This change in absorption is not caused by reversible DNA binding (e.g. intercalation), as the association constant for reversible DNA binding of unreduced TW13, determined with equilibrium dialysis, appeared to be smaller than $100 \mathrm{M}^{-1}$. However, the TW13 maximum

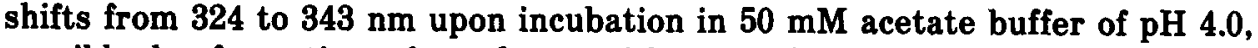
possibly by formation of products with opened aziridine rings, as demonstrated with carboquone [15]. TW13 is one of the most active compounds to cause DNA modifications in our previous study on BABQ [8]. Attempts to assay the alkylating activity of less active compounds were not successful, as no or very low additional absorption at wavelengths longer than $300 \mathrm{~nm}$ could be observed after reaction with DNA. 


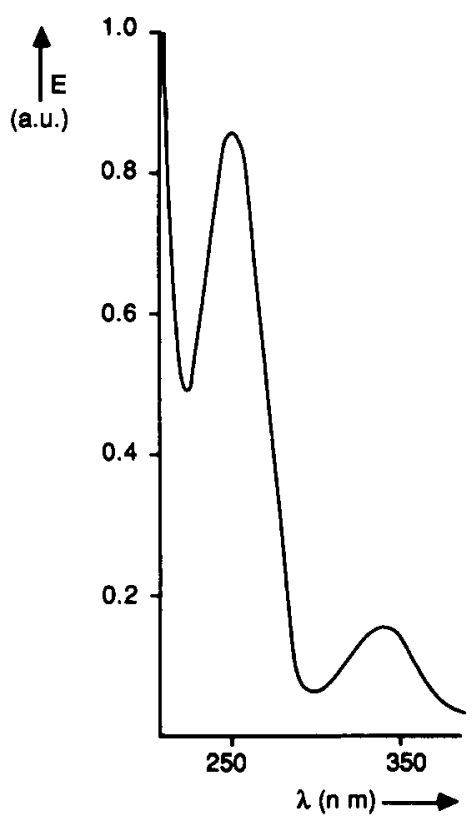

Fig. 2. Absorption spectrum of TW19 alkylated DNA. Calf thymus DNA $\left(1.2 \mathrm{mg} \cdot \mathrm{ml}^{-1} ; 3.6 \mathrm{mM}\right.$ as nucleotides) was incubated in TRIS - acetate buffer (pH 6.0) at $37^{\circ} \mathrm{C}$ during 60 min with electrochemically reduced TW13 $(0.25 \mathrm{mM})$. Unbound TW19 was removed by gel filtration and extraction.

Varying the extent of reduction of $T W 13$, a linear relation is observed between the extent of reduction and the amount of DNA adducts (Fig. 3). Therefore, reduction is essential for covalent binding of TW13 to DNA at pH 7.0.

We studied the pH dependence of DNA alkylation by $\mathrm{TW} 13$ in a $\mathrm{pH}$ range of 4.5-8.0. When the $\mathrm{pH}$ decreases, the amount of adduct increases (Fig. 4). At low $\mathrm{pH}$ ( $\mathrm{pH} \leqslant 4$ ), TW13 decomposes rapidly, so that alkylation does not increase any further, and eventually decreases. Furthermore, at $\mathrm{pH} \leqslant 4$, protonation of phosphate and amino groups of DNA occurs. This influences the reactivity of the electrophilic alkylating species. The observed reductiondependent and pH-dependent alkylation is fully in accordance with the concept that $B A B Q$ acts as reductively activated species in protonated form.

To study the consequences of DNA alkylation on the activity of DNA on a biological level, we studied the inactivation of bacteriophage M13mp19 DNA by TW13. As shown in Fig. 5, this inactivation was also dependent on both $\mathrm{pH}$ and reduction. TW13 induced inactivation of M13mp19 DNA increases with decreasing $\mathrm{pH}$ (curve b, Fig. 5). This effect is dramatically enhanced after reduction (curve c, Fig. 5). At low pH, M13mp19 DNA is damaged by pH effects (curve a, Fig. 5). The pH-dependence of inactivation of bacteriophage DNA can be fully explained by the increase of DNA alkylation 


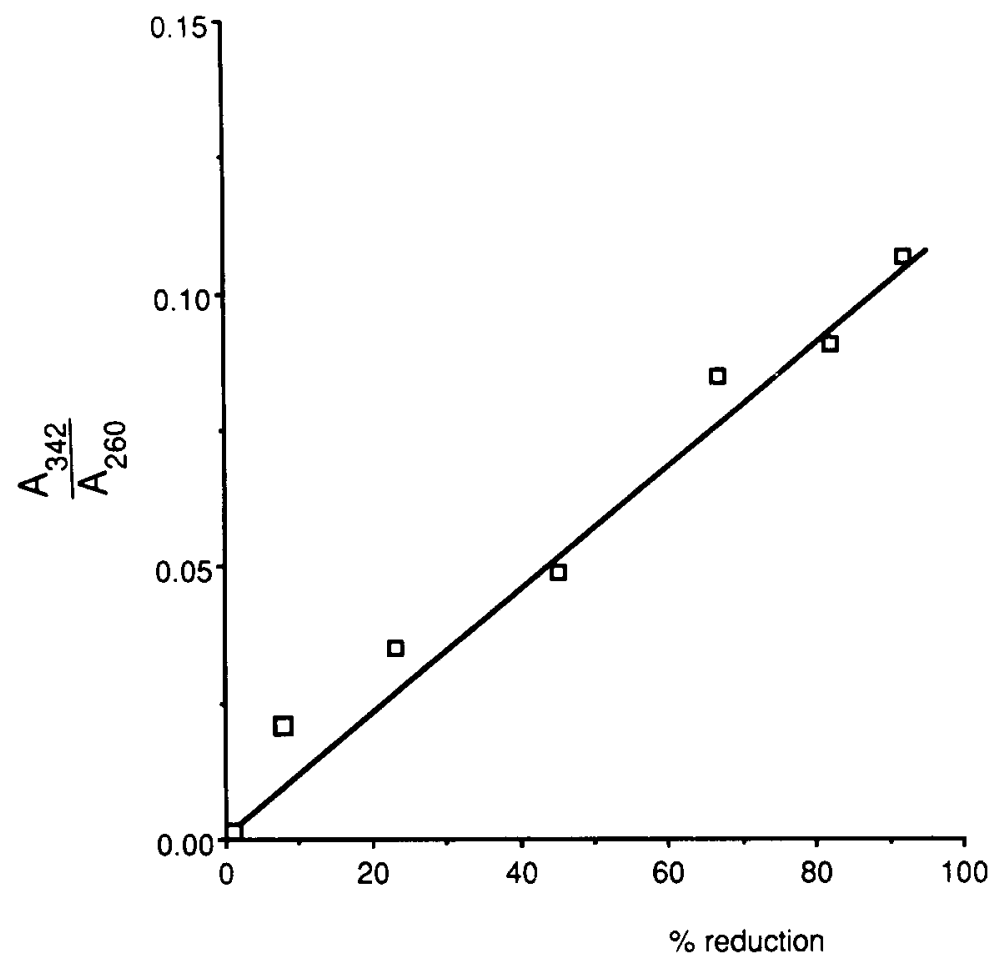

Fig. 3. Effect of extent of reduction on DNA alkylation by TW13. TW13 $(0.25 \mathrm{mM})$ was electrochemically reduced during different time intervals and incubated in $25 \mathrm{mM}$ TRIS-acetate buffer (pH 7.0) at $97^{\circ} \mathrm{C}$ during 60 min with calf thymus DNA $(0.75) \mathrm{mg} \cdot \mathrm{ml}^{-1} ; 2.2 \mathrm{mM}$ as nucleotides). Unbound TW13 was removed by gel filtration and extraction.

at lower $\mathrm{pH}$. The effect of reduction of TW13 on bacteriophage inactivation is also in accordance with the alkylating ability.

The cross-linking activity of our series of $\mathrm{BABQ}$ derivatives has been determined using the ethidium bromide fluorescence assay $[9,10]$. The results are shown in Fig. 6. TW23 (2-(1-aziridinyl)-1,4-napthoquinone) was used as a control, because it has only one aziridinyl group and therefore has no crosslinking potential. With TW23, no cross-linking activity at any $\mathrm{pH}$ was observed. The pH-profiles of cross-link formation are similar to that of DNA-alkylation by TW13 (Fig. 4). As in cross-linking two alkylation steps are involved, this result could indicate that the same mechanistic conditions control both DNA cross-linking and DNA alkylation.

The pH shift between the curves of reduced and unreduced drug are not the same for every compound (Fig. 6). This pH shift is expected to represent a difference in $\mathrm{p} K_{\mathrm{a}}$ value between the aziridine rings of the reduced and unreduced species. Driebergen [16] reported $\mathrm{p} K_{a}$ values of our unreduced $\mathrm{BABQ}$ compounds ranging from 2.4 to 4.0 and from 7.8 to 9.7 for the reduced $\mathrm{BABQ}$ compounds. The $\mathrm{p} K_{a}$ values of the unreduced compounds could not be 


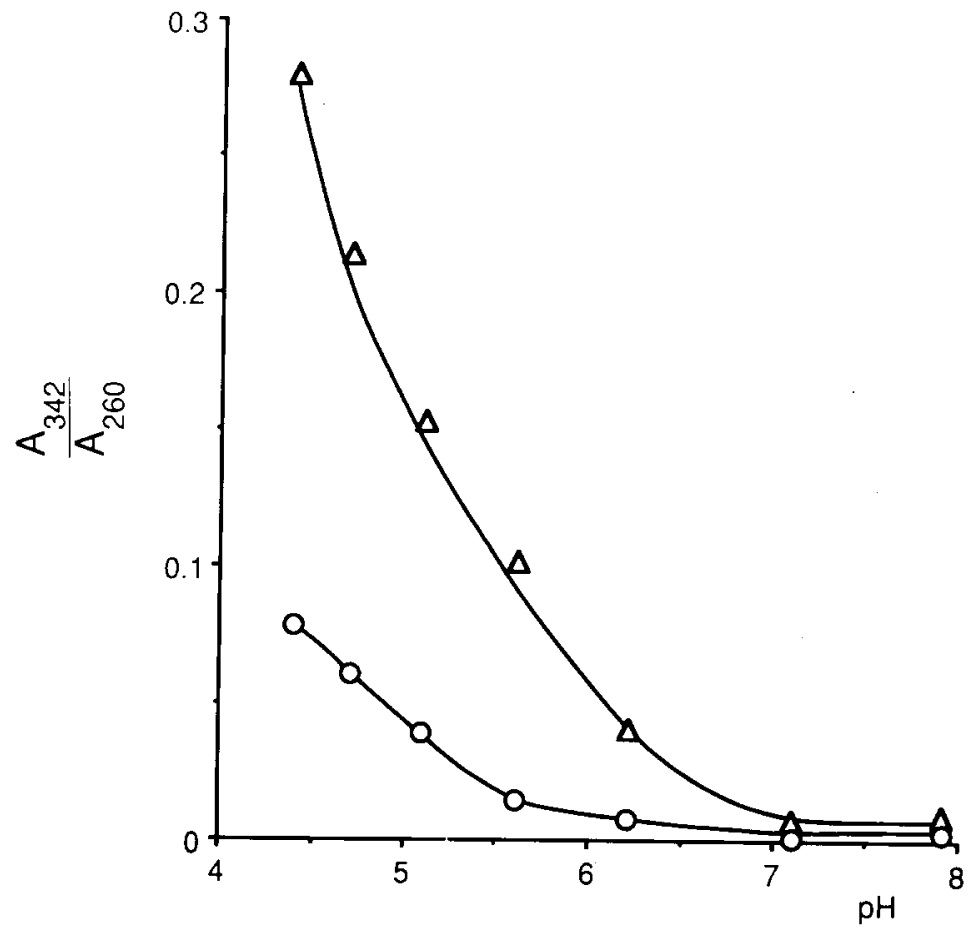

Fig. 4. pH-dependence of DNA alkylation by TW13. The reaction mixture contained calf thymus DNA (2 mM as nucleotides) and TW13 $(0.25 \mathrm{mM})$ in $100 \mathrm{mM}$ TRIS - acetate buffer of varying $\mathrm{pH}$. TW13 was electrochemically reduced $(\Delta)$ or used without reduction $(O)$.

determined accurately, since they are low, and at low pH degradation of the compounds is very rapid. The $\mathrm{p} K_{a}$ values of the reduced compounds have been determined as $\mathrm{pK}_{\text {red }}$ values, obtained from the $\mathrm{pH}$ dependence of electrochemical reductive cleavage of the aziridinyl ring, possible only after protonation [16]. These values appear to be $2-3 \mathrm{pH}$ units higher than the $\mathrm{p} K_{a}$ values that can be estimated from our cross-linking vs. $\mathrm{pH}$ curves. The $\mathrm{p} K_{\text {red }}$ values are indeed expected to be higher than the true $\mathrm{p} K_{a}$ values of the aziridinyl rings of the hydroquinone, due to hydroquinone adsorption to the mercury electrode, and competition between reductive and hydrolytic ring opening [16]. Moreover, in the determination of the $\mathrm{p} K_{\text {red }}$ values it is not taken into account that the $\mathrm{p} K_{a}$ value of the second aziridinyl ring could change, when the first aziridinyl ring has reacted with DNA.

When these drugs are to be used as bioreductively activated drugs against solid tumours, they must be unreactive at $\mathrm{pH} 7$ in oxidized form, but active in the reduced form, preferably at intracellular $\mathrm{pH}$, which for tumour cells is probably slightly acidic [3]. A high cross-linking potential and a large $\mathrm{p} K_{\mathrm{a}}$ shift after reduction are expected to be useful properties for drug selectivity against solid tumours. Carboquone, TW39 and to a lesser extent TW32 cause a high level of cross-link formation after reduction and are inactive at 


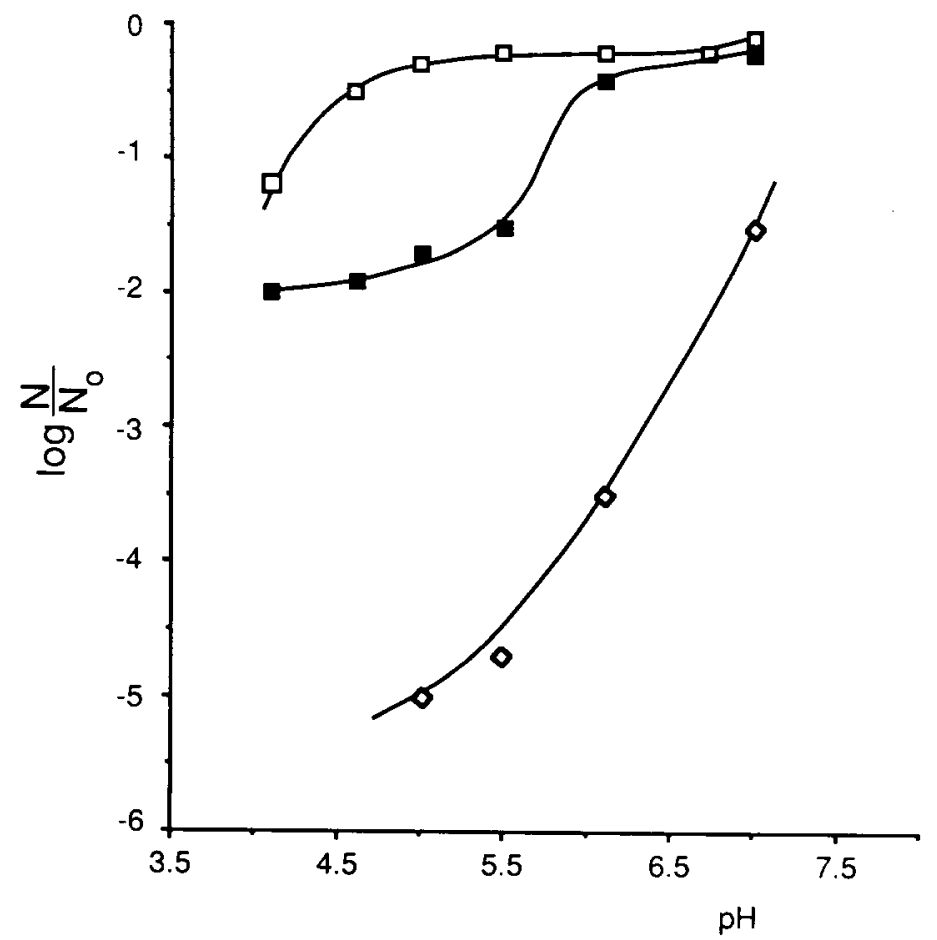

Fig. 5. Inactivation of single-stranded bacteriophage M13mp19, as assayed by transfection in $E$. coli JM 105. $N_{0}$ and $N$ are the number of plaques at $t=0$ and after exposure to TW13, respectively. $\square$ (curve a) incubation of M13mp19 DNA in TRIS-acetate buffers of varying $\mathrm{pH}$ during $1 \mathrm{~h}$ at $37^{\circ} \mathrm{C}$; (curve b), incubation in TRIS - acetate buffers of varying $\mathrm{pH}$ in the presence of $50 \mu \mathrm{M}$ TW13; $\diamond$ (curve c), incubation of TRIS - acetate buffers of varying $\mathrm{pH}$ in the presence of $50 \mathrm{mM}$ electrochemicaly reduced TW13.

physiological $\mathrm{pH}$ in the oxidized form. The oxidized form of TW13, however, forms cross-links already at $\mathrm{pH}$ 7.0, therefore TW13 is not expected to be a specifically useful drug.

Comparing the cross-linking activity with the previously determined DNA inactivation (Table II), we see that BABQ compounds containing a 2-methylaziridinyl group, which were the least active in the DNA inactivation tests, also produce the smallest amount of cross-links. A correlation between the amount of cross-links and inactivation of M13mp19 DNA or $E$. coli K12 can be observed (Fig. 7). The best correlation was between the inactivation of bacteriophage M13mp19 DNA (at pH 7.0) and the amount of cross-links at pH 5.0. Diaziquone (AZQ) produces relatively more cross-links than expected from its low activity in the DNA inactivation tests. King et al. [4] observed a comparable pH-dependence of cross-linking of calf thymus DNA with AZQ.

Of the studied BABQ derivatives, TW13, a very active compound in our previous DNA inactivation tests (Table II), produced a high amount of cross- 

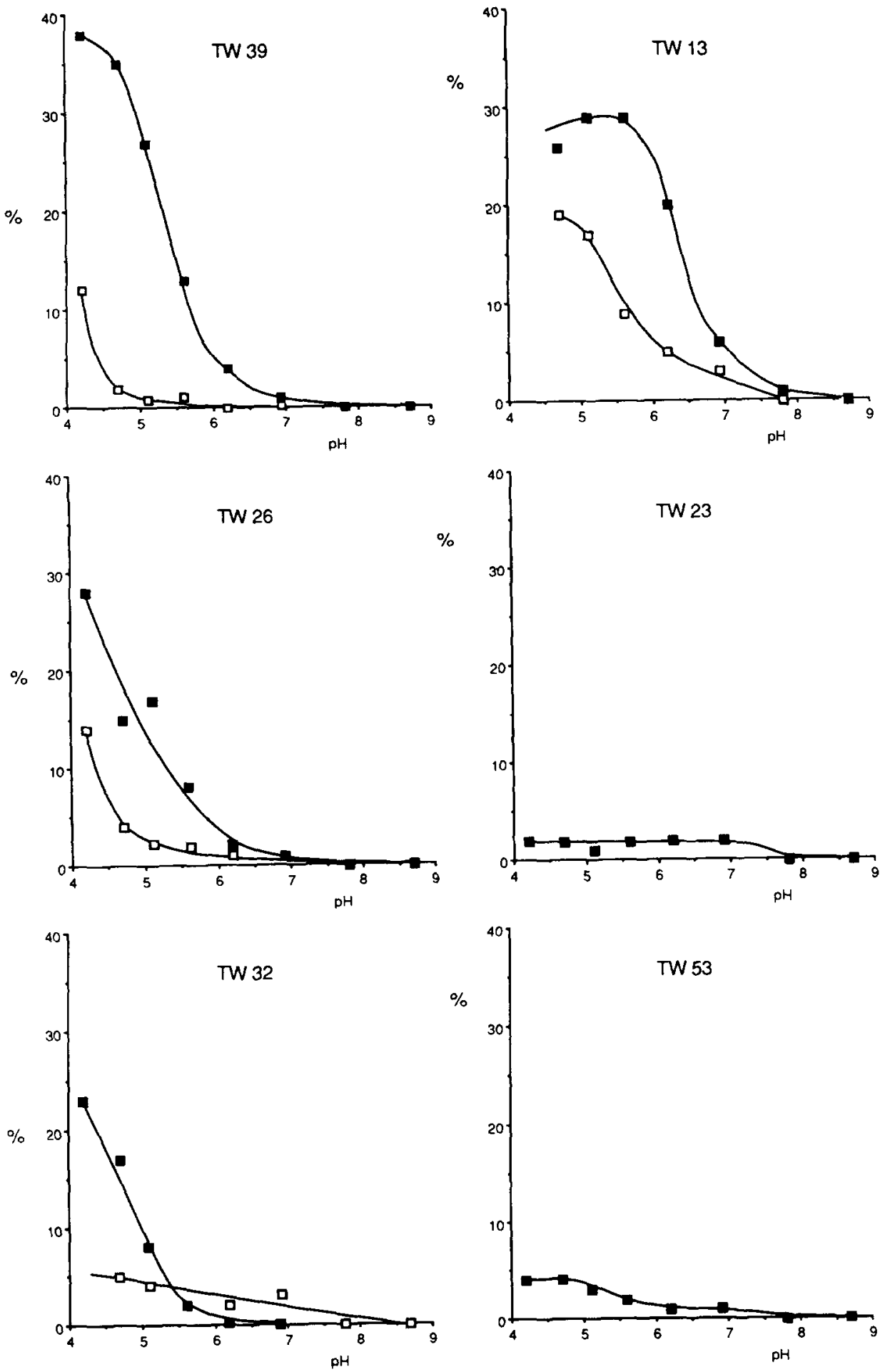

Fig. 6. pH-dependence of DNA-DNA interstrand cross-link formation in calf thymus DNA $(0.60$ $\mathrm{mg} \cdot \mathrm{ml}^{-1} ; 1.8 \mathrm{mM}$ as nucleotides) in $30 \mathrm{mM}$ TRIS - acetate buffer of varying $\mathrm{pH}$, by various $2,5-$ bis(1-aziridinyl) 1,4-benzoquinones $(0.005 \mathrm{mM})$, after electrochemical reduction $(\square)$ or without reduction ( $\square)$. DMF is a control experiment without BABQ compound. TW23 is a control experiment with a monofunctional aziridine compound, which cannot form DNA cross-links. 

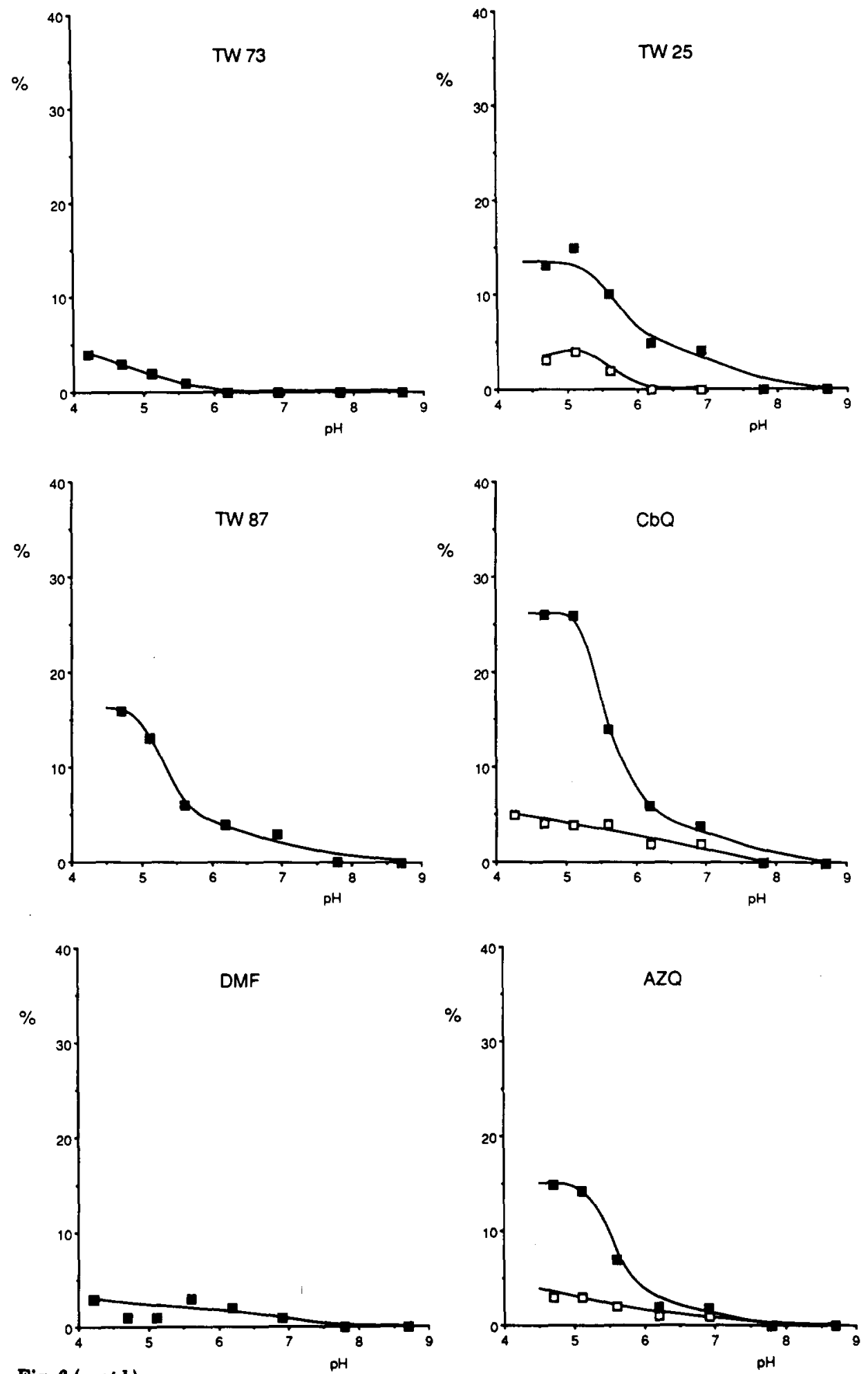

Fig. 6 (contd). 
TABLE II

ACTIVITIES OF 2,5-bis(1-AZIRIDINYL)-1,4-BENZOQUINONES

\begin{tabular}{llll}
\hline Compound & $\begin{array}{l}\text { Activity in } E . \text { coli k12 } \\
\text { DNA repair test }\end{array}$ & $\begin{array}{l}\text { Activity in M13 } \\
\text { DNA inactivation test* }\end{array}$ & $\begin{array}{l}\text { Percentage cross-linking } \\
\text { at pH = 5 with reduction }\end{array}$ \\
\hline AZQ & 0.03 & 0.03 & 14 \\
TW 73 & 0.03 & 0.04 & 2 \\
TW 53 & 0.04 & 0.06 & 3 \\
TW 87 & 0.07 & 0.13 & 13 \\
CbQ & 0.22 & 0.22 & 26 \\
TW 32 & 0.49 & 0.43 & 23 \\
TW 25 & 0.51 & 0.35 & 15 \\
TW 39 & 1.00 & 1.00 & 27 \\
TW 13 & 2.36 & 1.32 & 29 \\
TW 26 & 3.76 & 1.29 & 17 \\
\hline
\end{tabular}

Ref. 8.

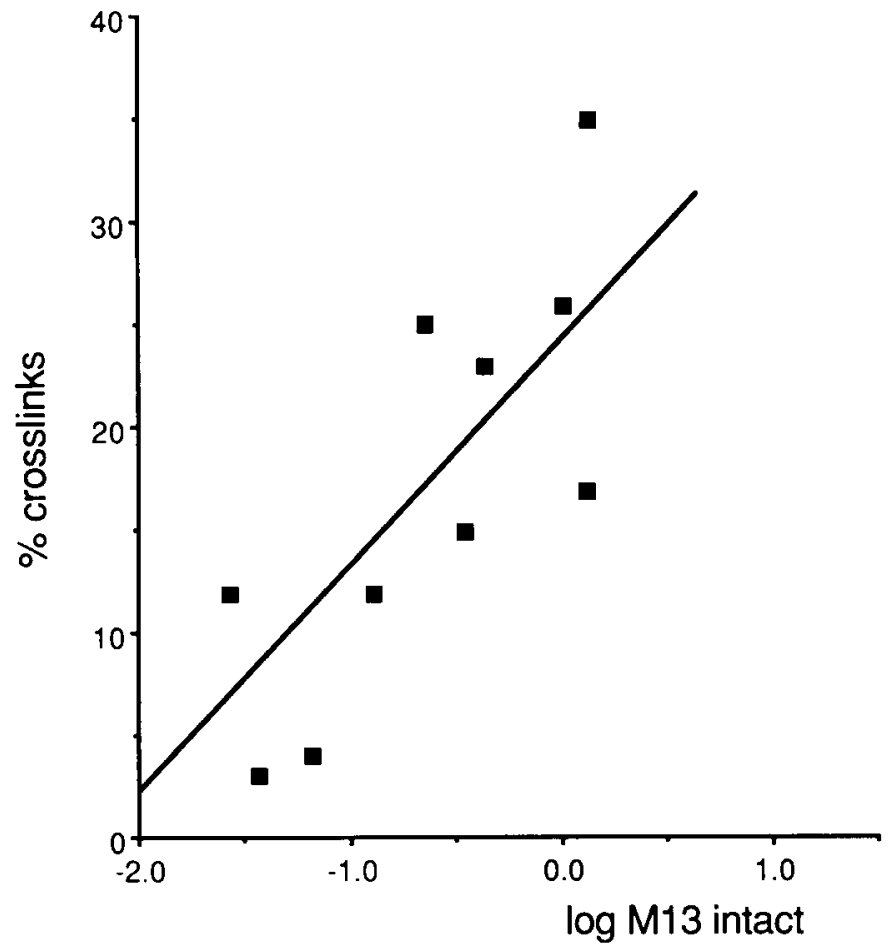

Fig. 7. Correlation between inactivation of bacteriophage M13mp19 DNA inactivation at pH 7.0 and the amount of cross-links at $\mathrm{pH} 5.0$ by the various BABQ compounds. $(n=10$; correlation coefficient $=0.78$ ). 


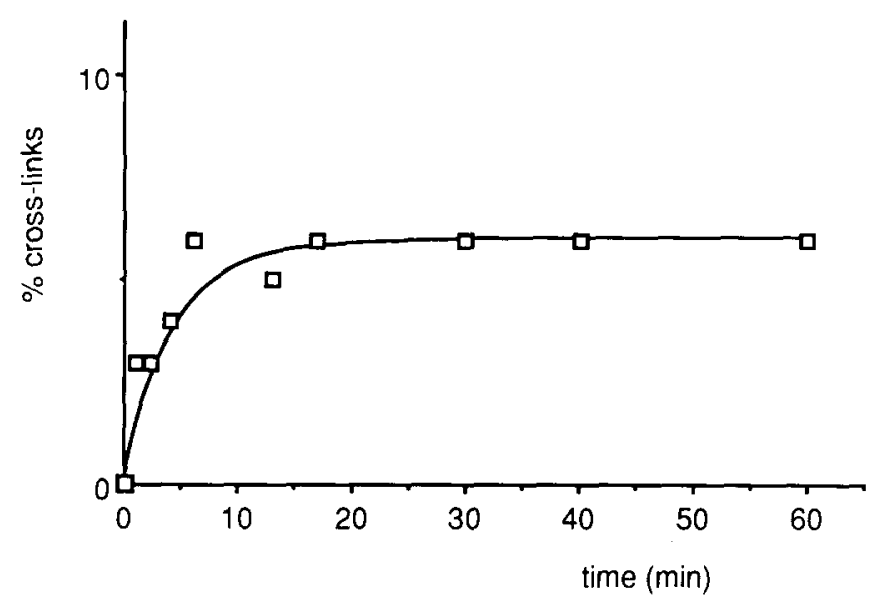

Fig. 8. Time-dependence of DNA interstrand cross-link formation in $E$. coli K12-343/765 by TW13. A suspension of $E$. coli $\mathrm{K} 12-343 / 765$ ( $\pm 10^{\circ}$ cells $\cdot \mathrm{ml}^{-1}$ ) in glucose-phosphate buffer (pH 7.1) was incubated with $\mathrm{TW} 13$ at $37^{\circ} \mathrm{C}$ under shaking. Samples were taken at different time intervals. DNA was isolated, and assayed for cross-links with the ethidium bromide fluorescence assay.

links at neutral pH $(6-7)$. Generally, the presence of more bulky $R_{1}$ and $R_{2}$ substituents decreases the amount of cross-links. The three compounds with methylated aziridine rings $\left(\mathrm{R}_{3}=\mathrm{CH}_{3}\right)$ produced very low amounts of crosslinks. These results confirm our previous finding that steric factors are important in the alkylation reaction [8].

To study cross-link formation on a cellular level, we used $E$. coli $\mathrm{K} 12$, in which TW13 is activated endogenously by bacterial reductases [8]. In Fig. 8 the formation of cross-links in $E$. coli K12-343/765 is shown. The amount of cross-links reaches a constant value after $20 \mathrm{~min}$. This plateau may be due to an equilibrium between cross-link formation and repair of cross-links. The viability of these DNA repair proficient cells remained unchanged by the TW13 treatment, while DNA repair deficient $E$. coli K12-343/753 (UVR-B', recA $^{-}$) were inactivated under these circumstances [8]. The alkylating electrophilic form of these aziridinyl compounds probably resembles that of the alkylating nitrogen mustards, the aziridinium cation [17]. Therefore, we expect that analogously to the mustard compounds the N7 of guanine is an especially likely candidate for alkylation [18]. The chemical nature of the DNA adducts evidently has to be established. To study this, experiments are in progress in our laboratory.

In summary, we demonstrated that 2,5-bis(1-aziridinyl)-1,4-benzoquinones are capable of alkylating DNA and forming DNA interstrand cross-links. Alkylation and cross-link formation are dependent on reduction and $\mathrm{pH}$ in such a way, that it can be concluded that reduction and protonation of the aziridine ring are mechanistic prerequisites for DNA alkylation. The biological consequences of DNA alkylation by BABQ derivatives may appear from the inactivation of bacteriophage DNA, which is apparently coherent with the extent of DNA alkylation. Furthermore, steric effects are important: 
$\mathrm{BABQ}$ derivatives with methylated aziridine rings and bulky 3,6-substituents have lower cross-link formation abilities.

$\mathrm{p} K_{a}$ shifts between the oxidized and reduced compound are different for the various BABQ derivatives. This offers perspectives for development of compounds with more selectivity for tumour cells.

\section{REFERENCES}

1 H.S. Schwartz, Mechanisms of selective toxicity of adriamycin, daunorubicin and related anthracyclines, in: Neidle and Waring (Eds.), Molecular Aspects of Anti-Cancer Drug Action, Verlag Chemie, Weinheim, 1983, pp. 93-125.

2 J.S. Driscoll, L. Dudeck, G. Congleton and R.I. Geran, Potential CNS anti-tumor agent IV: Aziridinylbenzoquinones III, J. Pharm. Sci., 68 (1979) 185- 188.

3 W.A. Denny and W.R. Wilson, Considerations for the design of nitrophenyl mustards as agents with selective toxicity for hypoxic tumor cells, J. Med. Chem., 29 (1986) 879-887.

4 C.L. King, S.K. Wong and T.L. Loo, Alkylation of DNA by the new anti-cancer agent 3,6diaziridinyl-2,5-bis(carboethoxyamino-1,4-benzoquinone (AZQ), Eur. J. Cancer Clin. Oncol., 20 (1984) $261-264$.

5 A.R.J. Silver and P. O'Neill, Interaction of the aziridine moiety of RSU-1069 with nucleotides and inorganic phosphate, Biochem. Pharmacol., 35 (1986) 1107-1112.

6 L. Szmigiero, L.C. Erickson, R.A. Ewig and K.W. Kohn, DNA strand scission and crosslinking by diaziridinylbenzoquinone (Diaziquone) in human cells and relation to cell killing, Cancer Res., 44 (1984) 4447-4452.

7 K.W. Kohn, DNA cross-linking agents, in: Y.C. Cheng et al. (Eds.), Development of TargetOriented Anti-Cancer Drugs, Raven Press, New York, 1983, pp. 181 - 188.

8 K.J. Lusthof, I.L. Groothuis-Pielage, J. Decuyper, N.J. de Mol, L.H.M. Janssen, W. Verboom and D.N. Reinhoudt, Potential antitumour 2,5-bis-(1-aziridinyl)-1,4-benzoquinones: Relationship between cytotoxicity against DNA repair deficient $E$. coli, inactivation of bacteriophage M13mp19 and in vitro and in vivo antitumour activity, Anti-Cancer Drug Design, 3 (1988) $147-155$.

9 J.W. Lown, A. Begleiter, D. Johnson and A.R. Morgan, Studies related to antitumor antibiotics. Part V. Reactions of mitomycin $\mathrm{C}$ with DNA examined by ethidium fluorescence assay, Can. J. Biochem., 54 (1976) 110-119.

10 S. de Jong, J.G. Zijlstra, H. Timmer-Bosscha, N.H. Mulder and E.G.E. de Vries, Detection of DNA cross-links in tumor cells with the ethidium bromide fluorescence assay, Int. J. Cancer, 37 (1986) $557-561$.

11 British patent 762723 (1956), Farb. Fab. Bayer A.G., Chem. Abstr., 51 (1957) 12153h.

12 T. Maniatis, E.F. Fritsch and J. Sambrook, Molecular Cloning. A Laboratory Manual, CSH Laboratory, Cold Spring Harbor, New York, 1982.

13 G.R. Mohn, The DNA repair host-mediated assay as a rapid and sensitive in vivo procedure for the determination of genotoxic factors present in various organs of mice, Arch. Toxicol., 55 (1984) 268- 271.

14 J. Marmur, A procedure for the isolation of deoxyribonucleic acid from micro-organisms, $J$. Mol. Biol., 3 (1961) 208-218.

15 A. Kusai, S. Tanaka and S. Ueda, The stability of Carboquone in aqueous solution. I. Kinetics and mechanisms of degradation of 2,5-diethylenimino-1,4-benzoquinone in aqueous solution, Chem. Pharm. Bull., 29 (1981) 3671-3679.

16 R.J. Driebergen, Qualitative and quantitative aspects of structure-electrochemistry-cytotoxicity relationships of aziridinylquinones, Ph.D. Thesis, Utrecht, 1987.

17 R.A., Pearlstein, S.K. Tripathy, R. Potenzone jr., D. Malhotra and A.J. Hopfinger, Physical association of two simple alkylators to some DNA sequences, Biopolymers, 19 (1980) $311-$ 324.

18 K.W. Kohn, J.A. Hartley and W.B. Mattes, Mechanisms of DNA sequence selective alkylation of guanine-N7 positions by nitrogen mustards, Nucleic Acids Res., 15 (1987), 1053110549 . 